\title{
THE PRESENCE OF LUSOPHONY IN THE EPISTEMIC FIELD OF Communication SCIENCES: 10 yeARS OF THEMED STUdies
}

\author{
Anabela Gradim, Paulo Serra \& Valeriano Piñeiro-Naval
}

\begin{abstract}
Drawing up a survey of publications on lusophone themes in the field of Communication Sciences over the last 10 years (2007-2017) has made it possible to describe that scientific production and find that it has been increasing in volume. This scientific production is feminised and focuses on two voices, where Portugal and Brazil take on a predominant role, which contrasts with the state of citations in the field in general. Based on the themes examined, Lusocom emerges as the great think tank for Lusophone Studies in the Communication Sciences field. "The presence of Lusophony in the epistemic field of Communication Sciences" is an exploratory, descriptive study that takes a quantitative-qualitative approach, covering a sphere that comprises the conference proceedings of Sopcom, Ibercom and the Anuário Internacional de Comunicação Lusófona published by Lusocom. Of the total of 3.252 articles found, a sample of 142 were chosen, selected by theme, to form the basis for this study.
\end{abstract}

\section{A PRESENÇA DA LUSOFONIA NO ESPAÇO EPISTÉMICO DAS Cî̂NCIAS DA COMUNICAÇÃo: 10 ANOS DE ESTUDOS TEMÁTICOS}

\begin{abstract}
RESUMO
Fazer a topologia das publicações de temática lusófona no campo das Ciências da Comunicação nos últimos 10 anos (2007-2017) permitiu caracterizar essa produção científica e constatar que esta vem aumentando, que é uma produção feminizada e essencialmente a duas vozes, onde Portugal e Brasil assumem um papel preponderante, que a bibliografia em Português é dominante, contrastando com o estado da citação na área em geral, e que, a partir das temáticas em foco, a Lusocom emerge como o grande think tank dos Estudos Lusófonos na área das Ciências da Comunicação. "A presença da lusofonia no espaço epistémico das Ciências da Comunicação" é um ensaio exploratório, descritivo, de abordagem quanti-qualitativa, com um universo que compreende as atas dos congressos da Sopcom, Ibercom, e o Anuário Internacional de Comunicação Lusófona editado pela Lusocom, num total de 3.252 artigos dos quais, atendendo à temática, foi selecionada uma amostra de 142 espécimes que constitui a base deste estudo.
\end{abstract}




\section{LUSOPHONY/LUSOPHONIES ${ }^{1}$}

Mapping the field of lusophone studies where it intersects with Communication Sciences is a considerable challenge that requires an operational definition of Lusophony from the outset.

Vítor de Sousa (2015) points out the imprecision of this term and traces its past back to the Estado Novo [New State] concept of Portugalidade, or 'Portugality', with 'Lusophony' being a post-colonial reconstructed version of this. Maciel (2010, p. 101) considers it the "sphere of communication and understanding, (...) the collection of cultural memory based on sharing a common language", and a community under construction reinvented in the light of a meeting of cultures, which is expressed in individual forms and many practices.

For Eduardo Lourenço, Lusophony is "the sphere of communication and understanding determined by the use of the Portuguese language with a genealogy that distinguishes it from other Romance languages and the cultural memory that, consciously or unconsciously, is attached to it" (Lourenço, 1999, p. 174). Since it is not simply a linguistic and phonetic fact, the "dispersed intangible continent" of Lusophony points to "a project, a dream and, even, a utopia undertaken" (Lourenço, 1999, p. 175). It has different configurations according to its topos in the lusophone space and, seen from Iberia, "Lusophony is above all, eminently, the fantastic expansion and drift of a language that took root as the language of national vocation and as culture" (Lourenço, 1999, p. 177).

Moisés Martins also discusses Lusophony as an "intangible continent" (Martins, Sousa \& Cabecinhas, 2006, p. 17) that "can only be understood as a space of culture" and that "today rallies a transnational community with political and cultural purposes" (Martins, 2004, p. 12), "based on a common language that largely goes beyond the language question" (Martins, 2004, p. 2), pointing towards an imagination of plurality and difference expressed in "multiculturisms with the common denominator of the same language" (Martins, 2004, p.12).

Helena Sousa, coordinator of the "Lusocom: estudo das políticas de comunicação e discursos no espaço lusófono" [Lusocom: studying communication policy and discourses in the lusophone space] project, effectively summarises the matter when she argues that "Lusophony is an extraordinarily difficult construction" because it is "a highly fragmented geo-linguistic space, a feeling full of contradictions, a memory of a common past, a multiple culture and a tense shared history" with a "symbolic heritage that is constantly disputed" and "institutions with political objectives that are themselves blurred and - not infrequently - contradictory or even conflicting" (Sousa, 2006a, p. 9).

Faraco $(2012$, p. 32) in turn distinguishes between use of the term Lusophony to refer to the Portuguese speakers in the world - "a descriptive use, which defines a certain quantity and, apparently, does not carry any greater political implications or evaluations" - and uses that are "marked by politics and by values", which are the object of endless meanings and complex disputes.

'T.N.: The words Lusophony and lusophone are used throughout this article to transmit the ideas of lusofonia and lusófono in Portuguese, which have meanings and connotations that are more specific than terms such as "Portuguese-speaking". 
Considering the debate in question, the semantic and ideological depth of the concept and the diversity of practices it covers, what we are interested in is finding an operational definition of Lusophony that can be mobilised to determine studies on the theme and comes close to a sense of the term that reflects a neutral linguistic reality.

In the Houaiss dictionary of the Portuguese language, Lusophony is established as "the group of those who speak Portuguese as their mother tongue or as a second language"; "the group of countries that have Portuguese as their official or dominant language" (Houaiss \& Villar 2002, p. 2323). For the Houaiss dictionary, Lusophony covers, as well as Portugal, the countries of Portuguese colonisation, and the varieties spoken by part of the population in regions where Portugal has made its presence felt. It therefore has extraordinary wealth, diversity and is spread over many areas, forming an enormously valuable cultural, political and geo-strategic reality.

The Portuguese language is present on many continents and is polycentric. While it remains the same language, it is spoken and written in different ways, corresponding to different histories, heritages, nearby languages, grammatical and pragmatic structures, cultural references and social uses. (...) it is a dynamic and many-sided reality. All varieties have the same value. There is no 'centre' for the Portuguese language, it does not have a standard norm and no-one can claim special rights of ownership over it. (Reto, Machado \& Esperança, 2016, p. 16)

As the fourth most widely spoken mother tongue in the world, Portuguese - the sharing of which we shall take as the common, distinctive feature of Lusophony, following the Houaiss definition - is the official language of eight countries: Angola, Brazil, Cape Verde, Guinea-Bissau, Mozambique, Portugal, São Tomé and Príncipe and East Timor. Their combined populations total 275 million speakers, representing $3.7 \%$ of the world's population (Reto et al., 2016, p. 61). Distributed over four continents, it is the "only global language without land borders" (Reto et al., 2016, p. 61)2. It is also the most spoken language in the Southern Hemisphere, and in 2016-2017 it was being studied by 200,000 foreign students in more than 70 countries. The total number of speakers is estimated to reach 390 million in the middle of the century, and 487 million by the end of the $21^{\text {st }}$ century (Reto et al., 2016, p. 57). As well as the geo-strategic side, it is a cultural and political asset for its speakers, a homeland and an "imagined continent" that challenges traditional north-south distinctions.

\footnotetext{
${ }^{2}$ The diaspora is also responsible for another 5.3 million native speakers, with significant communities in 22 countries: USA, Japan, Italy, France, Switzerland, Germany, the United Kingdom, Canada, South Africa, and many others (Reto et al., 2016, p. 63). There are six creoles based on Portuguese, most of which developed between the 16th and 18th centuries. Africa has the creoles of Upper Guinea and the Gulf of Guinea; India and Sri Lanka has the Indo-Portuguese creoles; Asia has Portuguese-based creoles in Malaysia and Indonesia; Sino-Portuguese creoles in Macau and Hong Kong; and in America there are Portuguese-influenced creoles in Aruba, Curaçau, Bonaire and Suriname (Reto et al., 2016, p. 69).
} 


\section{LUSOPHONE STUdies WITHIN CoMmunication SCIENCES}

This study is a bibliographic research aiming to map the academic production on matters of Lusophony in the field of Communication Sciences. It is an exploratory, descriptive study with a qualitative and quantitative approach that aims to contribute to knowledge and clarification in the field of lusophone studies within the scope of communication. The research surveys and compiles unprecedented data about a decade of studies in Portuguese in the field, which represent the effort to build a lusophone community and identity within Communication Sciences. The results contribute to a more documented reflection on the theme, making it possible to detect the origin, breadth and direction of scientific production in the field, the ongoing debate of ideas, and the perspectives, tensions and dominant themes in the knowledge production process in this field.

In a broad sense, lusophone studies are all studies expressed in one of the varieties of Portuguese. In this study, we are limiting that to include only those that directly or indirectly discuss the theme of Lusophony as a political, linguistic or cultural space or a space of memory.

To identify what we shall consider lusophone studies in the communication studies space, we shall turn to the dimensions of Lusophony as an institutional practice, but also in its applied form, producing the following six categories for classifying themes: theoretical articles; Lusophony policy and institutions; language policy; modes of lusophone expression; identity and otherness in lusophone communities; and representations of Lusophony in the media.

The sample includes the proceedings from the fifth to tenth conferences of Sopcom - Associação Portuguesa de Ciências da Comunicação [Portuguese Association of Communication Sciences], in a total of nine volumes ${ }^{3}$, the nine volumes of the Anuário Internacional de Comunicação Lusófona [International Yearbook of Lusophone Communication], published by the Federação Lusófona de Ciências da Comunicação [Lusophone Federation of Communication Sciences] ${ }^{4}$, and the proceedings of the 2011, 2013, 2015 and 2017 Ibercom conferences, published by Associação Ibero-Americana de Comunicação [lbero-American Communication Association] ${ }^{5}$. The full set for the 2007-2017 period, between proceedings and journals, comprises 22 volumes, forming a total of 3.252 articles, of which $142(4,4 \%$ of the total) were chosen because their themes represented lusophone studies.

The sample of 142 texts was organised into an SPSS database to consider 10 analysis variables: title, year of publication, number and gender of authors, country of the university of first author ${ }^{6}$, country discussed, origin/source of the work, type, primary and secondary themes, and bibliographic references.

\footnotetext{
${ }_{3}$ See https://www.sopcom.pt/page/eventos_cient_ficos\#congressos_sopcom

4 See http://www.intercom.org.br/lusocom/alusocom.shtml

${ }_{5}^{5}$ See http://www.assibercom.org/xvibercom2017/assibercom

${ }^{6}$ Regarding nationality, the only information that could be objectively codified based on the sources available was the university of origin. The category has some important limitations for interpreting the results, such as the fact that many of the studies originating in Portugal are carried out by researchers from other lusophone countries, with Brazilian students forming a significant proportion. Also, the same author may be classified as belonging to different countries over the decade as a result of his or her international academic career.
} 
The data was collected by way of qualitative observation from an analysis matrix established beforehand; the possibility of carrying out a keyword search was ruled out, since it would produce less precise results. Therefore, all works that, even if they do not mention the concept of "Lusophony", study, rework, establish or question that identity and community under construction (Maciel, 2010) in accordance with the six themes mentioned, were considered.

Within the six themes at the root of the selection and classification of the sample, theoretical articles are considered to be articles dealing with the clarification of concepts, methodological instruments, or the conceptualisation of the field; Lusophony policy and institutions are articles that deal with these things in a broad sense, including variations such as immigration, colonialism, media outlets as structures, and all the policy considerations that have an impact on Lusophony institutions, except those in the following category; language policy includes articles dedicated to explicit and implicit measures that regulate the community's language practices; modes of lusophone expression articles work on a lusophone product or achievement - whether symbolic, cultural or tangible; identity and otherness articles deal with construction or deconstruction of these ideas in lusophone communities; and representations of Lusophony in the media is the category for articles dealing with content analysis or critical discourse analysis regarding representations of concepts, groups, processes, or ideologies in the media.

The two most important Communication Sciences conferences in the lusophone space (Sopcom and Ibercom) and the annual volume published by Lusocom, which carries out the International Conference on Communication Sciences of Portuguese-speaking Countries, held for the $13^{\text {th }}$ time in $2018^{7}$, were chosen to form the sample. This is because these events represent the most important things being done in the field, forming a wider and more comprehensive sample than other types of publication, for example academic journals, since not all communications are embodied in that form. This choice also has the advantage of providing more focused data collection than journals, where the large variety available would make the sample diffuse.

\section{ResUlts}

In quantitative terms, the evolution in publishing between 2007 and 2017 reveals a consistent, sustained increase in scientific production, which is materialised as a rising line, as the graph in Figure 1 shows, with peaks in publication consistent with the twoyear frequency of the Sopcom and Ibercom conferences.

\footnotetext{
7 For a record of the ten Lusocom conferences held to data, see http://www.lusocom.net/eventos/
} 


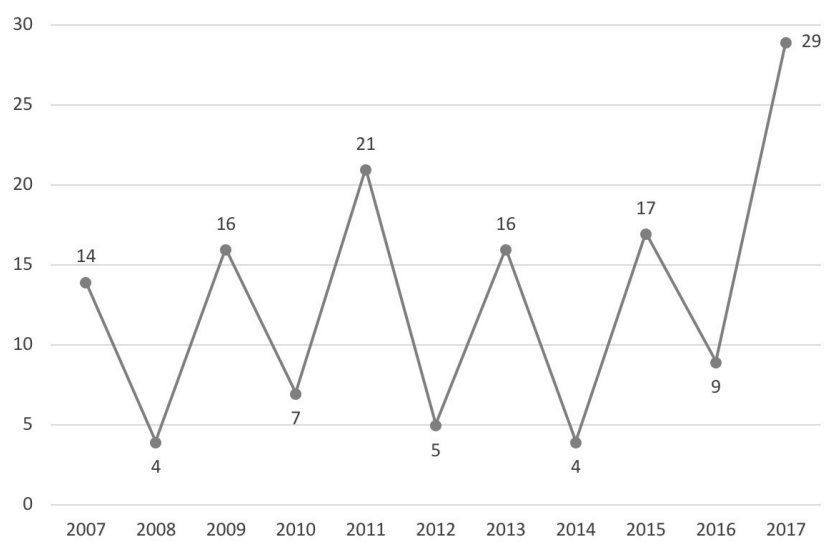

Figure 1: Annual timeline showing progression in publishing (number of works)

In terms of authorship, $65 \%$ of publications have one author $(n=93)$ and $35 \%$ are co-authored $(n=49)$, of which $22 \%$ have two authors. This represents $87 \%$ of publications, demonstrating that there are few texts with three or more authors.

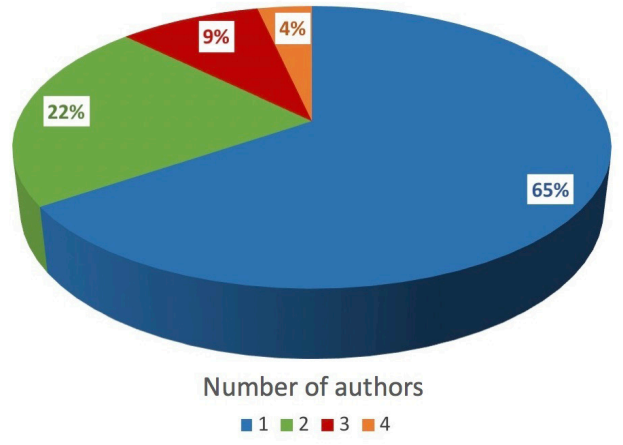

Figure 2: Percentage of studies with a single author and co-authored studies

In terms of gender, scientific output in the area is clearly dominated by women, who are responsible for the authorship of $57 \%(n=81)$ studies, while men are responsible for $43 \%(n=61)$, as regards first authors.

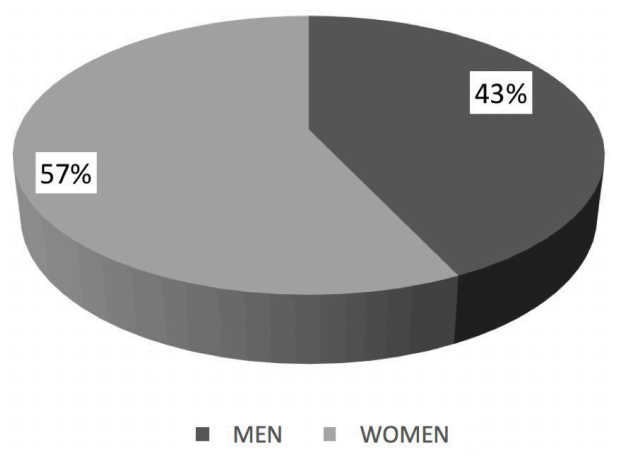

Figure 3: Percentage of articles by gender of authors 
This division by gender is also seen if we consider the sample in terms of quantity of scientific output, with three men among the group of nine authors who published the most. Additionally, in the case of these most productive authors, all of them began or spent time at the same research centre, CECS - Centro de Estudos de Comunicação e Sociedade [Communication and Society Research Centre] ${ }^{8}$, which reveals the central nature of this centre for lusophone studies within communication studies.

\begin{tabular}{lccc}
\hline \multicolumn{1}{c}{ NAME } & AUthor & Co-AUthor & TotAL \\
\hline Lurdes Macedo & 4 & 1 & 5 \\
\hline Moisés de Lemos Martins & 3 & 2 & 5 \\
\hline Rosa Cabecinhas & 2 & 3 & 5 \\
\hline Michelly Santos de Carvalho & 4 & 0 & 4 \\
\hline Vítor de Sousa & 3 & 0 & 3 \\
\hline Isabel Macedo & 2 & 1 & 3 \\
\hline Madalena Oliveira & 2 & 1 & 3 \\
\hline Regina Pires de Brito & 2 & 1 & 3 \\
\hline Silvino Lopes Évora & 2 & 1 & 3 \\
\hline
\end{tabular}

Table 1: Authors who published the most (number of publications)

Regarding the university/research centre of origin for authors at the time of publication, 62,7\% ( $n=89)$ published their work from Portugal; 25,7\% $(n=36)$ published their work from Brazil; 8,5\% ( $n=12)$ from Galicia/Spain; 1,4\% from Cape Verde, and 2,1\% from other countries.

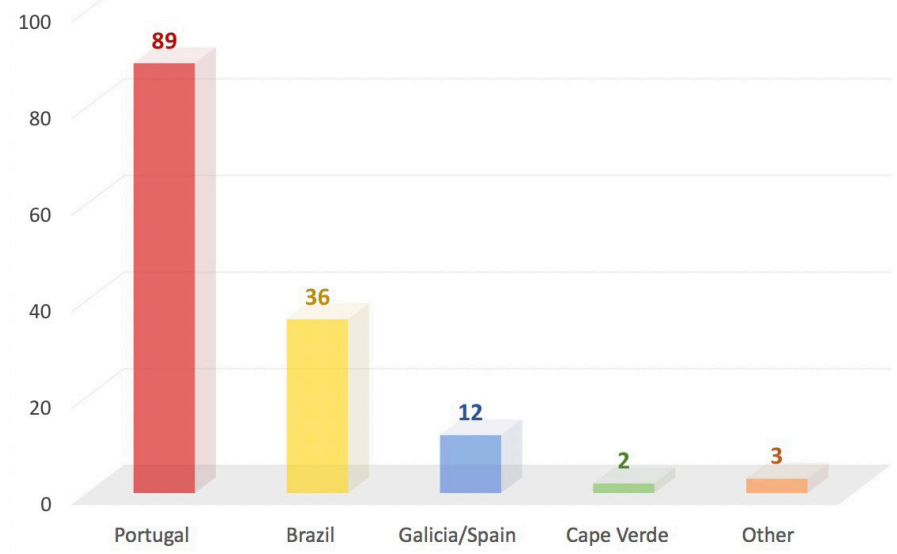

Figure 4: Number of publications by country of the university of the first author

\footnotetext{
${ }^{8}$ See http://www.cecs.uminho.pt/.
} 
The countries discussed in the articles in the sample are, in joint first place, Portugal and Brazil, reflecting a very wide range of studies carried out from a comparative perspective and which are transversal to all six themes considered in the classification of the sample, covering the entire range from theoretical works to media representation (31\%). This is followed by works that, focusing on Lusophony in general, have been considered to discuss lusophone countries as a whole (26,8\%). Portugal is the object of $21 \%$ of the studies, Brazil of 7,7\% and Angola and Cape Verde 3,5\% each. Mozambique, São Tomé and Príncipe, Guinea-Bissau and Timor represent figures below 3\%. To form this category, all the countries in the Comunidade dos Países de Língua Portuguesa [Community of Portuguese-speaking Countries] (CPLP) were taken into consideration, and it was later found that the sample also covered regions that do not belong to the organisation - Macau and Galicia - which have been included in the Others category.

\begin{tabular}{lc}
\hline \multicolumn{1}{c}{ CountrY } & $\%$ \\
\hline Portugal and Brazil & 31.0 \\
\hline All lusophone countries & 26.8 \\
\hline Portugal & 21.1 \\
\hline Brazil & 7.7 \\
\hline Angola & 3.5 \\
\hline Cape Verde & 3.5 \\
\hline Others & 2.8 \\
\hline Mozambique and São Tomé & 2.1 \\
\hline Guinea-Bissau & 0.7 \\
\hline Timor & 0.7 \\
\hline Total & 100 \\
\hline
\end{tabular}

Table 2: Countries discussed in the sample

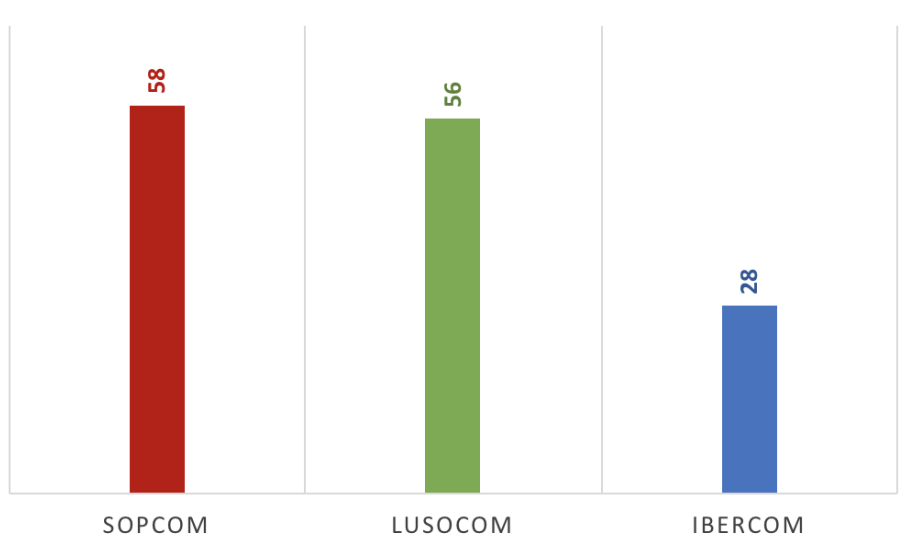

Figure 5: Number of articles by event of origin 
In terms of origin, $40,8 \%$ of the articles studied come from Sopcom conference proceedings; $39,4 \%$ originated in the nine volumes of the Anuário Internacional de Comunicação Lusófona [International Yearbook of Lusophone Communication] published between 2007 and 2017 ; and 19,7\% are articles published in the four volumes of proceedings of Ibercom that could be recovered relating to this period.

Each of the articles evaluated could potentially be classified into two of the six themes analysed, with a minority being considered to cover a single theme. Table 3 shows the distribution of primary and secondary themes by percentage, and reveals that the most common primary theme is Lusophony policy and institutions and the most frequent secondary theme deals with modes of lusophone expression. The least represented theme, as either primary $(10,6 \%)$ or secondary theme $(6,3 \%)$, is language policy.

\begin{tabular}{lclc}
\hline \multicolumn{1}{c}{ Primary theme } & $\%$ & \multicolumn{1}{c}{ SeCOndarY THEME } & $\%$ \\
\hline 1. Theoretical & 12,0 & 1. Theoretical & 13,4 \\
\hline 2. Institutions and policy & 30,3 & 2. Institutions and policy & 13,4 \\
\hline 3. Language policy & 10,6 & 3. Language policy & 6,3 \\
\hline 4. Lusophone expression & 14,8 & 4. Lusophone expression & 29,6 \\
\hline 5. Identity and otherness & 19,0 & 5. Identity and otherness & 13,4 \\
\hline 6. Media representation & 13,4 & 6. Media representation & 13,4 \\
\hline 7. Other & 0 & 7. Other & 4,2 \\
\hline Total & 100 & Total & 93,7 \\
\hline \multicolumn{4}{c}{ Table 3: Primary and secondary themes of the articles } \\
\end{tabular}

Regarding the themes, the three first categories (theoretical studies, institutions and policy) were grouped together, with articles in these categories considered as theoretical studies and articles in the other categories (lusophone expression, identity, representation) as applied works. This recoding of a polytomous variable into a dichotomous variable aimed to differentiate between theoretical studies and applied or practical works. Taking this new category as a starting point, some comparisons were made. The first is authors' genders, which made it possible to conclude that most men publish theoretical studies and are responsible for $49 \%$ of the total, while they are responsible for only $35,8 \%$ of applied studies. Women, on the other hand, are responsible for around half of theoretical studies and $64 \%$ of applied studies.

\begin{tabular}{llll}
\hline \multirow{2}{*}{ Gender } & \multirow{2}{*}{ \% Total } & \multicolumn{2}{c}{ Macro theme } \\
\cline { 3 - 4 } & & Theoretical & Applied \\
\hline Men & 43,0 & 49,3 & 35,8 \\
\hline Women & 57,0 & 50,7 & 64,2 \\
\hline $\mathrm{n}$ & 142 & 75 & 67 \\
\hline
\end{tabular}


Based on the data in Table 4, we can see that men tend to carry out theoretical work more than women, who focus their efforts on more practical or applied studies. However, these differences cannot be considered statistically significant $\left[X^{2}(1, N=142)\right.$ $=2.637, p=0.104]$.

As well as looking at the macro themes of the works by the authors' genders, it was also deemed relevant to know what type of publication was most common based on origin:

\begin{tabular}{llll}
\hline \multirow{2}{*}{ Origin } & \multirow{2}{*}{ \% Total } & \multicolumn{2}{c}{ MaCRo Theme } \\
\cline { 3 - 4 } & & Theoretical & \multicolumn{1}{c}{ Applied } \\
\hline Sopcom & 40,8 & $33,3^{-}$ & $49,3+$ \\
\hline Ibercom & 19,7 & 18,7 & 20,9 \\
\hline Lusocom & 39,4 & $48,0+$ & $29,9-$ \\
\hline $\mathrm{n}$ & 142 & 75 & 67 \\
\hline
\end{tabular}

Table 5: Origin of theoretical and applied works (\% column)

The cross referencing of this data, shown in Table 5, demonstrates that Sopcom publishes more applied works and that Lusocom publishes more theoretical works. These differences regarding the articles' origins show a statistically relevant trend $\left[X^{2}(2\right.$, $N=142)=5.241, p=0.073]$.

Regarding the number of bibliographic references in the articles, there are more in Portuguese $(M=11.12$; $S D=8.16)$ than in other languages $(M=10.06$; $S D=8.82)$. Although these differences are not statistically significant $[t(116)=0.892, p=0.374]$, the fact that Lusophone Studies in Communication Sciences have an average number of 11,12 lusophone authors, which is higher than the average number of references to authors from other origins and using different languages (10.06), contrasts starkly with the same average for the whole field (Serra, 2016), as we will see in the discussion of the results.

\section{DisCUSSION OF RESULTS AND CONCLUSIONS}

The results of this study show that lusophone studies have been increasing in quantity over the last decade, that most authors of applied or practical studies are women, that theoretical studies are concentrated on the Anuário Internacional de Comunicação Lusófona [International Yearbook of Lusophone Communication] and that male authors prefer the big theoretical issues. For this reason, Lusocom emerges as the great think tank of lusophone studies in the Communication Sciences field, an area that is essentially built around two voices, in which Portugal and Brazil have a predominant role. Bibliography in Portuguese also dominates, overtaking citations of authors of other languages on average, and contrasting with the state of citations in Communication Sciences in general. Most of the publications considered came from Portuguese universities, although authors could be students from other lusophone countries. The CECS research 
centre brings together the researchers that publish the most in this field, and the themes most frequently dealt with are Lusophony policy and institutions, followed by questions of identity and media representation.

These results show how the role of associations and conferences is fundamental in promoting Lusophony and confirm the greater involvement of Portugal and Brazil in the field. It should be noted that, of the twelve Lusocom conferences held to date, only two have been held outside Portugal, Brazil or Galicia: one in Mozambique ( $5^{\text {th }}$ conference, 2002) and the other in Cape Verde (12 ${ }^{\text {th }}$ conference, 2016), while five have been held in Portugal, three in Brazil, and two in Galicia. The $13^{\text {th }}$ Lusocom conference, in 2018 , is due to be held in Mozambique, where an association has been set up (Acicom - Associação Moçambicana de Ciências da Comunicação e da Informação [Mozambican Association of Information and Communication Sciences]). This association and Mediacom (Associação Cabo-verdiana de Ciências da Comunicação [Cape Verdean Association for Communication Sciences]) are the two Communication Sciences associations in the lusophone space outside the Portugal/Brazil/Galicia hub.

We also think it is highly significant that the citation of authors who write in Portuguese is much higher than in Communication Sciences in general, where most lusophone authors focus their references on anglophone authors (Serra, 2016). Recent studies have discussed the relationship between language and the political/material conditions of global neoliberal capitalism (Flores \& Chaparro, 2017; Joseph, 2006), the legacy of colonialism in the hegemony of the English language (Pennycook, 2017) and the problems faced by scientists in peripheral countries when disseminating science, observing that the academic publishing industry is a device that also serves to establish and maintain Western intellectual hegemony at global level (Canagarajah, 2002).

All science, however mathematical it may be, always involves a natural language to explain itself and make what it explains public. The natural language of sciences may today predominantly be English, which is due, on the one hand, to the economic, political, military, media-cultural hegemony of the Anglo-Saxon world, particularly the USA and, on the other hand, an anglophone ethnocentrism that is actively accepted by its very victims. Fighting against that ethnocentrism involves, for each marginalised natural language, and Portuguese in particular, achieving critical mass in research and publication that forces the large scientific book and journal publishers to translate into English and not just from English. Translating is exactly that: leaving one "worldview" (Humboldt, $1836 / 1988)$ to enter another, promoting dialogue between different views of the world, and refusing to distinguish between centres and peripheries.

Scientific capitalism, with its classification and evaluation devices, language policing and publishing industry geared towards English speakers, is a system that intensifies inequalities between emerging fields of different research and publishing cultures. Language policy and linguistic struggles, present in the academic publishing industry, have a considerable impact on that symbolic and material distribution of scientific resources (Gradim \& Piñeiro-Naval, in press).

As Moisés Martins has said, "in a post-colonial, globalised age, linguistic and cultural choices express the struggle for the symbolic ordering of the world" (Martins, 2015, 
p. 16). This is how "a language can only assert its strength through the information and knowledge it carries", which should be manifested "in literary terms and in scientific, cultural and artistic terms", and therefore the language struggle should be manifested in publishing and cultural and scientific policy in the countries that speak the language (Martins, 2015, p. 16).

The positive features uncovered by this study therefore include, for lusophone studies, the question of hetero-reference and ethnocentrism, which is not a negligible component in the "language struggle" mentioned by Moisés Martins, and appears to be moving in the right direction. In terms of the balance between the different centres of Lusophony, we have observed that this is still mostly being built by three voices, Portugal/Brazil/Galicia, and that even in Portugal it is highly concentrated at the University of Minho's CECS.

Strategies for improving and broadening participation by other members of the Community of Portuguese-speaking Countries will need to include organising Lusocom conferences in places outside Portugal, Galicia or Brazil (with their support, when necessary), setting up and developing Communication Sciences associations in all lusophone countries that do not yet have any, and the involvement of researchers from several countries in joint education and research projects (Serra, 2017).

This, the first study on the profile of lusophone studies in the epistemic field of Communication Sciences, is limited by the nature of the sample - focused on the field's conferences - and the construction of the measurement indicator, which is qualitative. Mapping the field of Communication Sciences, future studies may involve broadening the research sample by searching for publications in databases such as Scielo, WoS and Scopus, setting the epistemic field of its origin based on journals in which it is found, which will make it possible to view lusophone studies in communication along with the other fields where it takes place, and by covering a wider window of time, not limited to the last decade.

Translation: Tom Williams

\section{REFERENCES}

Canagarajah, S. (2002). Reconstructing local knowledge. Journal of Language, Identity and Education, 1(4), 243-259. DOI: 10.1207/S15327701JLIEO1O4_1

Faraco, C. A. (2012). Lusofonia: utopia ou quimera? Língua, história e política. In T. Lobo, Z. Carneiro, J. Soledade, A. Almeida \& S. Ribeiro (Org.), Rosae: linguística histórica, história das línguas e outras histórias (pp. 31-50). Salvador: EDUFBA.

Feytor Pinto, P. (2010). O essencial sobre política da língua. Lisboa: Imprensa Nacional Casa da Moeda.

Fiorin, J. L. (2009). Língua, discurso e política. Alea: Estudos Neolatinos, 11(1), 148-165. DOI: 10.1590/ S1517-106X2009000100012

Flores, N. \& Chaparro, S. (2017). What counts as language education policy? Developing a materialist Antiracist approach to language activism. Language Policy, 1-20. DOI:10.1007/s10993-017-9433-7

Gradim, A. \& Piñeiro-Naval, V. (in press). Policies for Portuguese and Spanish: the world's second publication languages in Web of Science. 
Houaiss, A. \& Villar, M. de S. (2002). Dicionário Houaiss da língua portuguesa. Elaborado no Instituto Antônio Houaiss de Lexicografia e Banco de Dados da Língua Portuguesa. Rio de Janeiro: Círculo de Leitores.

Humboldt, W. (1836/1988). On Language: on the diversity of human language construction and its influence on the mental development of the human species. Cambridge: Cambridge University Press.

Joseph, J. E. (2006). Language and politics. Edinburgh: Edinburgh University Press.

Lourenço, E. (1999). A Nau de Ícaro seguido de imagem e miragem de lusofonia. Lisboa: Gradiva.

Maciel, C. (2015). A construção da comunidade lusófona a partir do antigo centro: micro-comunidades e práticas da lusofonia. Lisboa: Camões - Instituto da Cooeração e da Língua.

Martins, M. L. (2004, abril/maio). Lusofonia e luso-tropicalismo: equívocos e possibilidades de dois conceitos hiper-identitários. Opening Conference at the X Congresso Brasileiro de Língua Portuguesa, Pontifícia Universidade Católica, São Paulo. Retrieved from http://repositorium.sdum.uminho.pt/ handle/1822/1075

Martins, M. L. (2012). Revistas científicas de Ciências da Comunicação em Portugal: da divulgação do conhecimento à afirmação do Português como língua de pensamento. Intercom: Revista Brasileira de Ciências da Comunicação, 35(1), 233-251. Retrieved from http://www.scielo.br/pdf/interc/v35n1/12.pdf

Martins, M. L. (2015). Lusofonia e interculturalidade - promessa e travessia. V. N. Famalicão: Húmus.

Martins, M. L., Sousa, H. \& Cabecinhas, R. (Eds.) (2006). Comunicação e lusofonia: para uma abordagem crítica da cultura e dos media. Porto: Campo das Letras.

Pennycook, A. (2017). The cultural politics of English as an international language. London: Routledge.

Reto, L., Machado, F. L. \& Esperança, J. P. (2016). Novo atlas da língua portuguesa. Lisboa: Imprensa Nacional Casa da Moeda.

Serra, J. P. (2016). O (des)conhecimento recíproco dos investigadores ibero-americanos de Ciências da Comunicação. Revista Lusófona de Estudos Culturais, 3(2), 57-68. Retrieved from http://www.rlec.pt/ index.php/rlec/article/view/115

Serra, J. P. (2017). A lusofonía como projeto em construção. Anuário Internacional de Comunicação Lusófona 2015-16: metodologias da pesquisa, cibercultura, regulação e cooperação, 1, 19-25.

Sousa, H. (2006a). Comunicação e lusofonia: do lugar acrítico ao lugar da procura. In M. L. Martins, H. Sousa, \& R. Cabecinhas (Eds.), Comunicação e Lusofonia: para uma abordagem crítica da cultura e dos media (pp. 9-14). Porto: Campo das Letras.

Sousa, H. (2006b). A mobilização do conceito de lusofonia: o caso dos canais internacionais da RTP. In M. L. Martins, H. Sousa, \& R. Cabecinhas (Eds.), Comunicação e lusofonia: para uma abordagem crítica da cultura e dos media (pp. 165-182). Porto: Campo das Letras.

Sousa, V. M. (2015). Da 'portugalidade’ à lusofonia. Vila Nova de Famalicão: Húmus.

\section{BIOGRAPHICAL NOTES}

Anabela Gradim has an undergraduate degree in Philosophy from the University of Porto, and has a master's degree and PhD with Agregação in Communication Sciences from the University of Beira Interior, where she gained her PhD with the thesis $A$ 
dimensão comunicacional da semiótica de Peirce. She teaches journalism, communication and methodology at the University of Beira Interior's Faculty of Arts and Letters, where she runs the PhD in Communication Sciences. She is a researcher at Labcom.IFP - Laboratory of Online Communication and coordinates the Communication and Media Group. Her research interests deal with journalism, communication science, semiotics, rhetoric, and the intersection of these fields with cyberculture and new media.

Email: anabela.gradim@labcom.ubi.pt

Address: Universidade da Beira Interior, Av. Marquês D’Ávila e Bolama, 6200-001 Covilhã

Joaquim Paulo Serra has an undergraduate degree in Philosophy from the Lisbon Faculty of Letters and a master's degree and PhD with Agregação in Communication Sciences from the University of Beira Interior (UBI). At UBI, he is a professor in the Department of Communication and Arts and a researcher at the Labcom.IFP - Communication, Philosophy and Humanities R\&D unit. He is currently scientific coordinator of Labcom. IFP at UBI and Chair of the Portuguese Association of Communication Sciences (Sopcom). He wrote the books A informação como utopia (1998), Informação e sentido: o estatuto epistemológico da informação (2003) and Manual de teoria da Comunicação (2008), and co-authored Informação e persuasão na web (2009). He organised the book Retórica e política (2015) and has co-organised several other books, the last of which was Televisão $e$ novos meios (2017). He has also written several chapters of books and articles published in Portuguese and foreign collective works and journals.

ORCID: https://orcid.org/oooo-0001-7821-3880

Email: pserra@ubi.pt

Address: Universidade da Beira Interior, Av. Marquês D’Ávila e Bolama, 6200-001 Covilhã

Valeriano Piñeiro-Naval has an undergraduate degree in Advertising and Public Relations (University of Vigo) and Audiovisual Communication (University of Salamanca). He has a European PhD in Audiovisual Communication, Technological Revolution and Cultural Change from the University of Salamanca, and is currently a member of the Labcom.IFP - Communication, Philosophy and Humanities R\&D unit at University of Beira Interior, where he is currently using a post-doctoral grant from Portugal's Foundation for Science and Technology (FCT).

ORCID: https://orcid.org/0000-0001-9521-3364

Email: vale.naval@labcom.ubi.pt

Address: Universidade da Beira Interior, Av. Marquês D’Ávila e Bolama, 6200-001 Covilhã

* Submitted: 15.05 .2018

* Accepted: 12.07.2018 